\title{
Caracterização estrutural de um segmento da rampa lateral de Capitólio, limite norte da nappe de Passos (MG)
}

\author{
Tiago Eloi de Souza Sério dos Santos ${ }^{1}$ \& Luiz Sérgio Amarante Simões ${ }^{2}$
}

\begin{abstract}
Resumo O limite norte da nappe de Passos, sudoeste de Minas Gerais, é marcado por um sistema de rampa lateral denominado de Rampa Lateral de Capitólio. Nesse contexto, essa rampa é o contato entre os Domínios Interno e Externo da Faixa Brasília Meridional. O estudo detalhado desses domínios permite considerar um modelo para evolução dessa rampa, explicando como a estruturação vertical marcante no Domínio Externo, transiciona para a estruturação subhorizontal encontrada no Domínio Interno, ambas com direção NW-SE. O contato entre esses domínios é balizado por um cavalgamento tardio $\left(\mathrm{D}_{3}\right)$ que oblitera os registros iniciais do desenvolvimento da rampa lateral, um plano íngreme $\left(\mathrm{D}_{2}\right)$. A parte oculta dessa história envolveu modelos complexos de deformação, onde através da rotação do eixo de vorticidade transiciona de uma Zona de Cisalhamento Monoclínica do tipo Y vertical para uma horizontal, respectivamente na posição de rampa e patamar da nappe.
\end{abstract}

Palavras-chave: nappe de Passos, rampa lateral, geologia estrutural, zonas de cisalhamento monoclínicas.

\begin{abstract}
Structural mapping of a Capitólio lateral ramp section, northern edge of Passos nappe - Minas Gerais state, Brazil. The northern edge of Passos nappe, southwest of Minas Gerais state, is marked by a lateral ramp system called Capitólio Lateral Ramp. This ramp is the contact of the Internal and External domains of the Southern segment of the Brasilia Fold Belt. A detailed study of these domains permits to consider a model for the evolution of this ramp, explained as the vertical structures, which marks External Domain, changing to sub-horizontal structures verified in Internal Domain, both striking NW-SE. The contact between these domains is distinguished by a later thrust $\left(\mathrm{D}_{3}\right)$ which obliterates the initial registers of the development of the lateral ramp, a steep plane $\left(\mathrm{D}_{2}\right)$. The covered portion of this history involved complex deformation models, where by rotation of the vorticity axis is possible to see a transition of a vertical to horizontal Y-Monoclinic Shear Zone, respectively in the ramp and flat of the nappe.
\end{abstract}

Keywords: Passos nappe, lateral ramp, structural geology, monoclinic shear zones.

INTRODUÇÃO É comum notar em cinturões orogênicos a presença de traços de cavalgamentos fortemente convexos em direção ao antepaís (ex. Himalaia, Andes, Alpes, etc). Estruturas curvadas junto com muitos dos complexos modelos de deformação vistos em zonas de cisalhamento e cinturões de cavalgamentos, podem ser explicados através de um deslocamento diferencial ao longo dos grandes planos de empurrão (Coward \& Potts 1983). As diferenças de deslocamento ao longo desses planos são acomodadas por zonas de falhas dispostas em alto ângulo com o trend regional (Coward \& Potts 1983, Pohn 2000). As falhas direcionais maiores associadas a estruturas curvadas são geralmente consideradas como rampas laterais.

O termo "rampa lateral" foi usado por Boyer \& Elliot (1982) e Butler (1982), para descrever limites tectônicos paralelos à direção geral de transporte de lâminas de cavalgamento.

No Neoproterozóico a colisão entre os crátons São Francisco, Amazônico e Paranapanema, resultou em inúmeras superfícies de cavalgamento, que com- põem a denominada Faixa de Dobramentos Brasília (Schobbenhaus et al. 1984). Traços arqueados de cavalgamento são comuns na Faixa Brasília Meridional (FBM), compondo um complexo sistema de nappes de cavalgamentos indicando grandes transportes em direção ao Cráton do São Francisco no período entre 640 Ma e 600 Ma. (Teixeira \& Danni 1978, Simões 1995a, Valeriano et al. 1995 e 2000, Seer 2001).

Um desses cavalgamentos reconhecidos na FBM delimita a nappe de Passos (NP). A parte frontal dessa nappe é representada pelo Sistema de Cavalgamentos Ilicínea-Piumhi e o limite norte pela Rampa Lateral de Capitólio (Valeriano et al. 2004). Ao longo desse cavalgamento, metassedimentos de fácies xisto verde médio (zona da biotita) a anfibolito superior, do Grupo Araxá (Simões 1995a) cavalgam metassedimentos de baixo grau do Grupo Canastra, além de rochas atribuídas ao embasamento e ao Grupo Bambuí.

Utilizando a situação geológica reconhecida na NP (Fig. 1), aplicou-se a metodologia tradicional para 


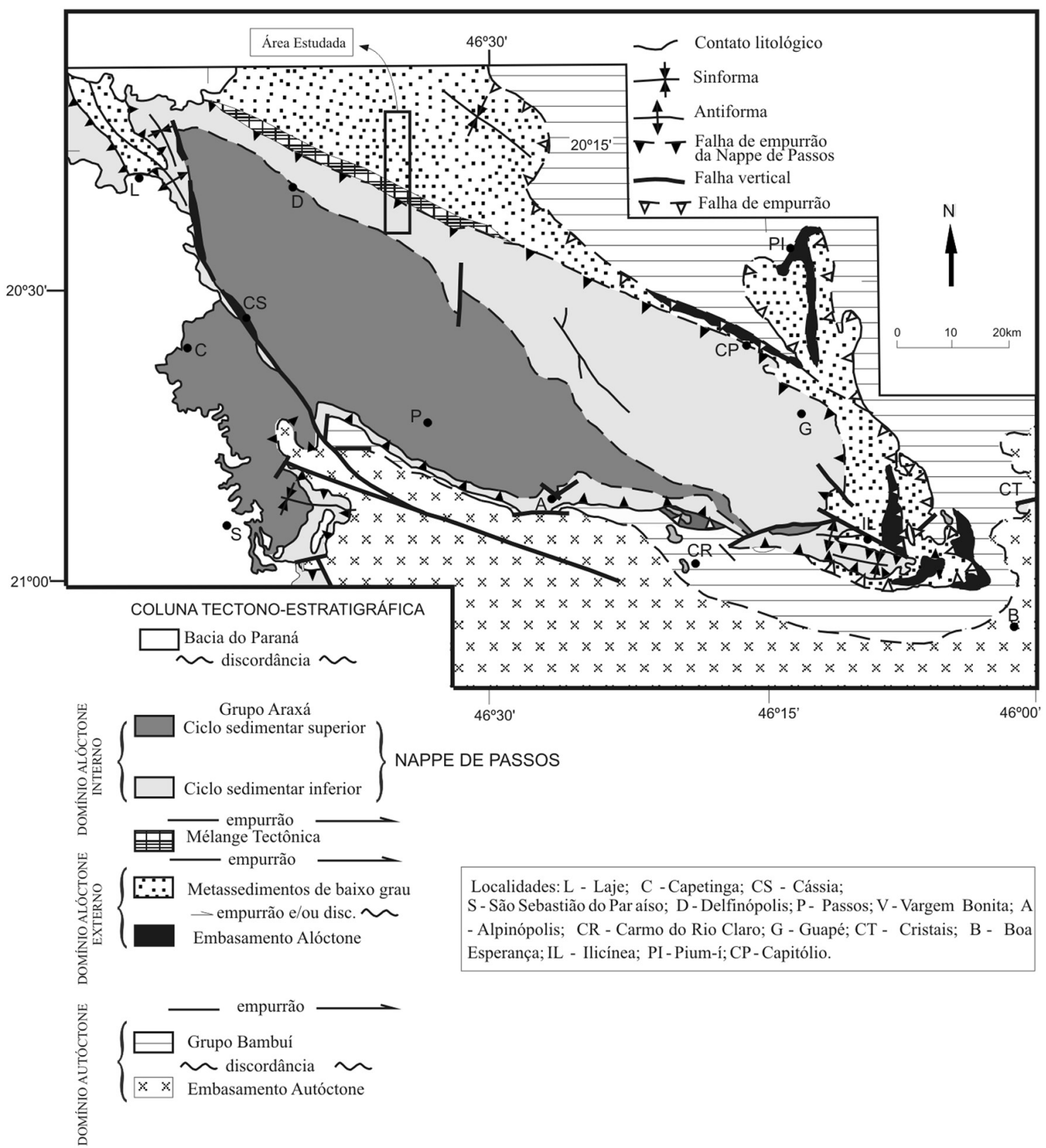

Figura 1 - Mapa geológico simplificado da nappe de Passos com indicação da área mapeada. Modificado de Simões \& Valeriano (1990).

mapeamento geológico acompanhado das técnicas de análise cinemática meso e microscópica (Passchier \& Trouw 1996), para caracterizar a variação do padrão estrutural presente ao longo de uma seção transversal cortando o limite norte da NP, desde o domínio cavalgado, passando pela rampa lateral, até o domínio cavalgante.

A caracterização individual de rampas laterais é comum na literatura (Coward 1980, Lamotte \& Guezou 1995; Passchier et al. 1997, Santos 2007), mas a maioria dos estudos é realizada em situações onde predominaram processos rúpteis. Além de visar o entendimento da formação e evolução de rampas laterais, a motivação para realização desse trabalho reside na carência de bibliografia referente ao desenvolvimento de estruturas de rampas em níveis crustais mais profundos, que corresponde à maioria dos casos do Brasil onde os cinturões orogênicos estão arrasados.

RAMPAS LATERAIS EM SISTEMAS DE CAVALGAMENTOS As rampas laterais (RL) são os limites tectônicos paralelos à direção geral de transporte de lâminas de cavalgamento; nessas rampas a componente de movimento direcional é a principal e, se a rampa possuir alto ângulo funciona como uma verdadeira zona transcorrente. Elas são geradas pela necessidade de se transferir o deslocamento perpendicularmente à direção do empurrão, podendo ser originadas por mecanismos atuantes durante ou subseqüente aos cavalgamentos.

Pohn (2000) apresenta quatro configurações básicas possíveis para geometria de RLs, (Fig. 2), da mais simples para a mais complexa: RLs paralelas ligadas a um plano de descolamento horizontal (Fig. 2A); RLs parale- 


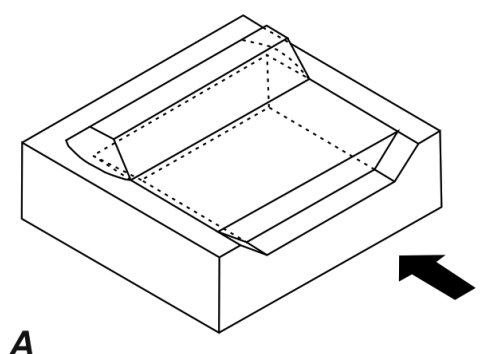

$\boldsymbol{A}$

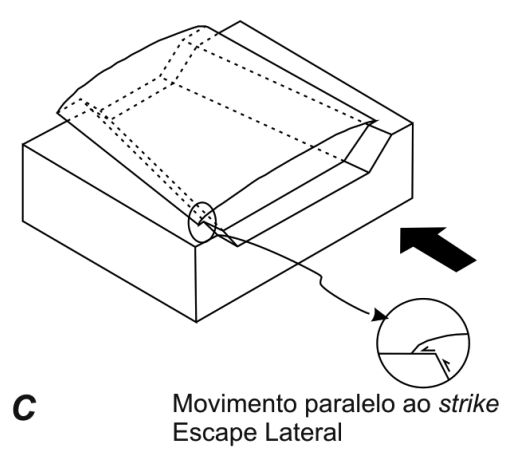

Figura 2 - Blocos diagramas simplificados, mostrando quatro geometrias básicas possíveis para formação de rampas laterais (Pohn 2000).
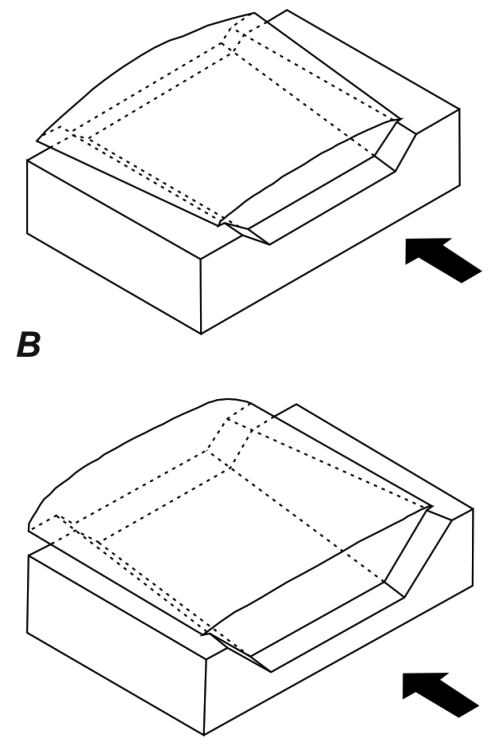

D las com um descolamento inclinado ascendente (Fig. 2B); RLs convergentes conectados a um plano de descolamento horizontal (Fig. 2C) e RLs convergentes ligados a um plano de descolamento inclinado ascendente (Fig. 2D).

Seções transversais às RLs em cada um desses modelos, com exceção do primeiro, mostrariam que para se acomodar os movimentos seria necessária uma espécie de escape lateral, com um movimento paralelo à direção das camadas, causado inteiramente pela diminuição do espaço em direção ao sentido de transporte.

$\mathrm{O}$ próprio autor desses modelos menciona o paradoxo criado pelos terceiro e quarto modelos, que já representariam rampas oblíquas, e levanta uma discussão: até que ponto de obliqüidade com o sentido de transporte as rampas deveriam ser consideradas como laterais ou oblíquas? E ainda cita a dificuldade em se determinar isso em rampas em que houve escape lateral, que acaba ocultando a rampa original. No Brasil o termo "rampa oblíqua" é pouco utilizado, sendo que as falhas perpendiculares a aproximadamente perpendiculares à frente de empurrões são genericamente chamadas de RL.

Os modelos acima apresentados são muitos simplistas, demonstrando de forma geral apenas a geometria das rampas que pode ser desenvolvida na formação de lâminas de cavalgamentos. A RL enfocada neste artigo desenvolveu-se sob condições dominantemente dúcteis, por isso o seu entendimento deve ser considerado no contexto de uma Zona de Cisalhamento Dúctil.

As estruturas desenvolvidas em uma zona de cisalhamento simples são relativamente bem conhecidas e esse modelo é geralmente usado nos estudos que envolvem zonas de cisalhamento.

Em situações rúpteis, normalmente com me- tamorfismo em fácies xisto verde inferior (Passchier 1998), esse modelo funciona bem, com a deformação se concentrando em planos/faixas com limites bem definidos por rochas menos deformadas/indeformadas. Mas em zonas de cisalhamento dúcteis, especialmente em graus metamórficos mais elevados, a deformação da massa rochosa se dá pela ação conjunta de cisalhamento simples e puro; o que faz com que o modelo de cisalhamento simples torne-se uma simplificação, se afastando, às vezes, da realidade.

Sanderson \& Marchini (1984) chamaram de transpressão (transpression) uma zona de cisalhamento vertical/subvertical em que há aproximação das paredes limitantes e de transtração (transtension) onde ocorre distanciamento das mesmas, com essas variações causadas apenas por encurtamento ou estiramento subhorizontal que, sob volume constante, são compensados somente por estiramento vertical ou encurtamento, respectivamente.

Esses modelos antecederam o conceito de zona de cisalhamento monoclínica (Passchier 1997 e 1998), no qual foram agrupados além de cisalhamento simples, transpressões e transtrações, zonas de cisalhamento nas quais o estiramento/encurtamento é compensado por encurtamento ou estiramento, perpendicular às paredes limitantes; e zonas de cisalhamento onde ocorrem variações no volume.

Passchier (1998) apresentou os tipos de zonas de cisalhamento monoclínicas $X_{I}, Y_{I}$ e $Z_{I}$ (Fig. 3), como uma maneira mais prática de classificá-las com observações reais de campo. Essa classificação é feita com base no elipsóide de deformação finito em relação ao vetor de vorticidade, w. Cada tipo de zona monoclínica (X, Y e Z) 


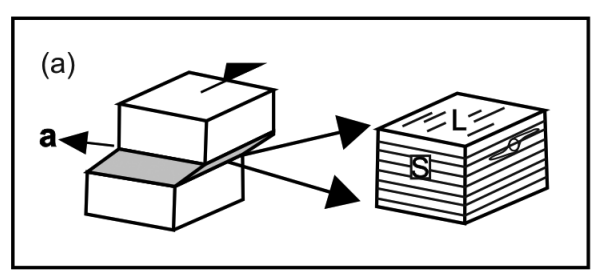

TIPOS DE ZONAS DE CISALHAMENTO MONOCLÍNICAS

(b) Tipos de zonas de cisalhamento monodínica

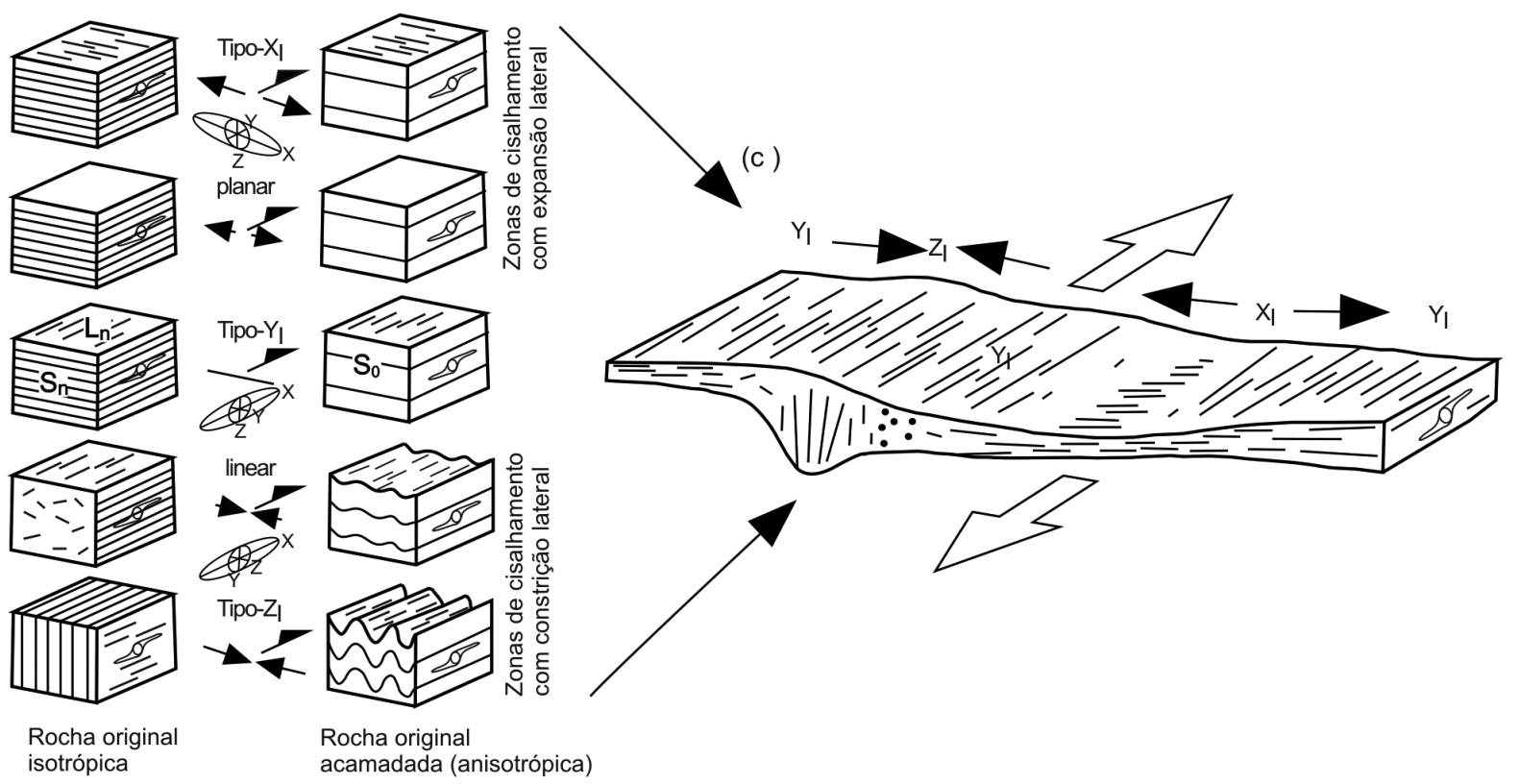

Figura 3 - (a) Esquema mostrando a orientação dos elementos que formam a trama de uma zona de cisalhamento dúctil. A zona de cisalhamento apresenta uma simetria monoclínica, tendo o eixo a normal a direção de transporte (seta cortada), e paralelo ao vetor de vorticidade. As assimetrias das estruturas são melhores observadas num plano normal ao eixo a. (b) Trama desenvolvida, e orientação de $S$ e L nos diferentes tipos de zona de cisalhamento monoclínica $\left(X_{p} Y_{I}\right.$ e $Z$ ). Elipsóides de deformação finita, mostrando a posição dos eixos em relação ao sentido de transporte (seta cortada) e ao eixo a (seta). (c) Esquema mostrando a possivel variação lateral entre os diferentes tipos de zonas de cisalhamento monoclínicas que podem ocorrer ao longo de uma zona de cisalhamento. (Modificado de Passchier 1997 e Passchier et al. 1997).

é denominada pelo eixo do elipsóide de deformação que se encontra paralelo ao vetor de vorticidade.

Em situações reais, esses diferentes tipos de zonas de cisalhamento monoclínicas podem gradar um para o outro, gerando complexidades nessas áreas de transição, que podem ser facilmente confundidas com a ação de mais de uma fase de deformação.

GEOLOGIA REGIONAL A área estudada (Fig. 1) está inserida no contexto da FBM, a parte sul de um grande cinturão orogenético neoproterozóico que se estende por volta de $1000 \mathrm{~km}$ na direção N-S. A FBM pode ser dividida em Domínios Interno (DI) e Externo (DE), que se sobrepõem ao Cráton do São Francisco através de superfícies de cavalgamento que mergulham aproximadamente para $\mathrm{W}$.

Domínio Interno Na área enfocada o DI é representado pela $N P$, uma importante unidade tectônica situada no sudoeste do estado de Minas Gerais, destaca- da primeiramente por Teixeira \& Danni (1978) e que, posteriormente teve seus limites melhor definidos pelos trabalhos de diversos autores (Morales et al. 1983, Heilbron et al. 1987, Simões et al. 1990, Valeriano et al. 1995, Simões 1995a). Esta nappe se estende por pelo menos $150 \mathrm{~km}$, na direção NW-SE, sendo limitada a norte pela denominada Rampa Lateral de Capitólio (Valeriano et al. 1995), uma estrutura originalmente dúctil de movimento sinistrógiro, mas que possivelmente teve reativações tardias em fases mais rúpteis; a sudeste é limitada pelo Sistema de Cavalgamentos Ilicínea-Piumhi; e a sul, próximo a São Sebastião do Paraíso, por zonas de cisalhamento verticais com direção E-W relacionadas ao Cinturão de Cisalhamento Campo do Meio (Morales 1993).

O Grupo Araxá, no contexto da nappe de Passos, foi dividido por Simões (1995a) em nove unidades litoestratigráficas, denominadas da base para o topo de $\mathrm{A}$ a I. As três primeiras unidades (A, B e C), compõem o Ciclo Deposicional Inferior, caracterizado por sedimen- 
tação essencialmente matura (quartzitos e metapelitos), representando metassedimentos plataformais. Esse ciclo evolui transicionalmente para o Ciclo Deposicional Superior, formado pelas unidades $\mathrm{D}$ a I, que são compostas essencialmente por xistos e paragnaisses, representando participação de sedimentação imatura em um ambiente de plataforma profunda a talude continental. Rochas metabásicas são encontradas subordinadamente ao longo de toda seqüência, representando possivelmente basaltos continentais e basaltos do tipo E-MORB (Valeriano1992, Valeriano et al. 2000 e Simões et al. 1998).

Zanardo (1992) e Simões (1995a) também destacam a ocorrência de um metamorfismo invertido para as rochas que compõem a nappe de Passos, onde os dados geotermobarométricos indicam auge metamórfico variando de $450^{\circ} \mathrm{C}$ e $6 \mathrm{kbar}$ na base a $750^{\circ} \mathrm{C}$ e $11 \mathrm{kbar}$ no topo. $\mathrm{O}$ auge metamórfico é datado de $640+/-4 \mathrm{Ma}$ (U-Pb) (Valeriano et al. 2004). Essa inversão pode ser explicada pelo arrasto das isotermas em fases precoces da orogênese brasiliana, associado a uma zona de subducção que mergulhava aproximadamente para W. Posteriormente, essas rochas foram rapidamente exumadas e empurradas contra o Cráton do São Francisco, preservando a inversão das isotermas geradas na zona de subducção (Simões 1995a).

Domínio Externo O DE é cavalgado pela $N P$ e cavalga o Domínio Cratônico. O limite entre esse domínio e o DI (nappe de Passos), no contexto estudado, é marcado pela Rampa Lateral de Capitólio. As rochas que compõem o DE, na área trabalhada, são basicamente: quartzitos, xistos e filitos atribuídos ao Grupo Canastra; a sudeste, é representado por rochas do Grupo Bambuí e pelo Sistema de Cavalgamentos Ilicínea-Piumhi, detalhado por Valeriano (1999), composto por numerosas escamas de empurrão, que envolvem rochas arqueanas pertencentes ao Greenstone-belt de Piumhi e metassedimentos de baixo grau metamórfico de idade posições duvidosas, também cavalgadas pela nappe de Passos, em situação de rampa frontal.

Na região de Tapira, Silva (2003) reconheceu vários domínios litotectônicos (denominados de Domínios Norte, Sul, Leste e Oeste) e definiu as rochas correlacionáveis com o Grupo Canastra como metassedimentos representantes de ambientes de plataforma proximal (Domínio Sul) e plataforma distal (escamas: inferior e intermediária, Domínio Leste; e, escama 1, Domínio Oeste). Os metassedimentos interpretados como depositados em ambiente de plataforma proximal foram metamorfisados em fácies xisto verde inferior e se encontram pouco deformadas, estando preservados grãos sedimentares e estruturas primárias, como acamamento e marcas de onda. Os metassedimentos atribuídos a plataforma distal estão mais deformados e o metamorfismo nessas unidades alcança graus mais elevados, atingindo a zona da granada da fácies xisto verde nas escamas Intermediária (DE) e 1 (DW) (Silva 2003).

Geologia Estrutural da Faixa Brasília Meridional A FBM é marcada por cavalgamentos em direção a leste que promoveram a imbricação de diferentes unidades litoestratigráficas, dispostas com orientação aproximada- mente NNW. São registradas ocorrências de diversas zonas de cisalhamento verticais com direção WNW-ESE, algumas contemporâneas aos cavalgamentos (ex. Rampa Lateral de Capitólio (Valeriano et al. 1995, Simões 1995a), outras posteriores (ex. Zona de Cisalhamento da Canastra (Silva 2003)), e outras ainda não estudas em detalhe suficiente. Em função deste padrão estrutural, identifica-se na FBM uma compartimentação vertical marcada pela imbricação de domínios litotectônicos definidos por escamas de empurrão e, uma compartimentação longitudinal devida aos truncamentos causados pelas zonas de cisalhamento transversais (Silva 2003).

O padrão estrutural descrito para nappe de Passos inclui 4 fases deformacionais, sendo as duas primeiras as mais importantes, responsáveis pela formação da foliação principal $\left(\mathrm{S}_{1} / / \mathrm{S}_{2}\right)$ e pelo transporte da nappe $\left(\sin -\mathrm{D}_{2}\right)$. A foliação $\mathrm{S}_{2}$ geralmente é paralela à estratificação primária $\left(\mathrm{S}_{0}\right)$. Sobre a foliação $\mathrm{S}_{2}$ observa-se uma forte lineação mineral de direção $\mathrm{WNW}-\mathrm{NW}$ presente em todos os níveis estratigráficos, à qual são paralelos os eixos das abundantes dobras apertadas a isoclinais da fase $\mathrm{D}_{2}$. Os indicadores cinemáticos observados evidenciam transporte tectônico para ESE (Simões 1995a).

Esse padrão estrutural descreve bem a situação geral descrita para a nappe de Passos, mas é incompleta para a parte norte, onde as estruturas tornam-se mais complexas devido à presença da rampa lateral. Nessa região predomina uma foliação vertical, mas ainda ocorre, em variados graus de intensidade e penetratividade, uma foliação de baixo ângulo que corta as estruturas de alto ângulo. A seqüência de superposição das estruturas de alto e baixo ângulo, bem como a cinemática e o significado tectônico das foliações de baixo ângulo tardias, ainda não são bem compreendidas (Simões 1995b).

Já no Domínio Externo, na região de Tapira, Silva (2003) descreve o desenvolvimento de seis fases de deformação, sendo que as duas primeiras, juntamente com o $\mathrm{S}_{0}$, geraram uma foliação composta $\left(\mathrm{S}_{0} / / \mathrm{S}_{1} / / \mathrm{S}_{2}\right)$, caracterizada pelo paralelismo de três estruturas, a estratificação primária $\left(\mathrm{S}_{0}\right)$ e duas foliações tectônicas $\left(\mathrm{S}_{1}\right.$ e $\mathrm{S}_{2}$ ). Essa foliação composta é dobrada com amplitudes quilométricas pela fase $\mathrm{D}_{3}$, sendo posteriormente cortada pela foliação $\mathrm{S}_{4}$, a mais marcante na área mapeada pelo autor acima citado e, provavelmente, correspondendo à foliação $\mathrm{S}_{2}$ descrita por Simões (1995a) na nappe de Passos. No item Análise Cinemática é apresentada uma tabela (Tab. 1, página 370) comparativa entre as fases deformacionais descritas para o DI e DE, modificada de Silva (2003) e com os dados do presente trabalho.

\section{GEOLOGIA DA ÁREA ESTUDADA}

Compartimentação Tectônica Adotada Segundo os critérios propostos por Simões e Valeriano (1990), que se baseiam no grau de deformação/ recristalização e metamorfismo das rochas, somados às informações estruturais aqui obtidas, dividimos a área estudada nos Domínios Interno e Externo da FBM (Fig. 4). O limite entre esses dois domínios, nessa área, é marcado por uma grande falha oblíqua, que coloca lado a lado os referidos domínios, chamada de Rampa Lateral de Ca- 


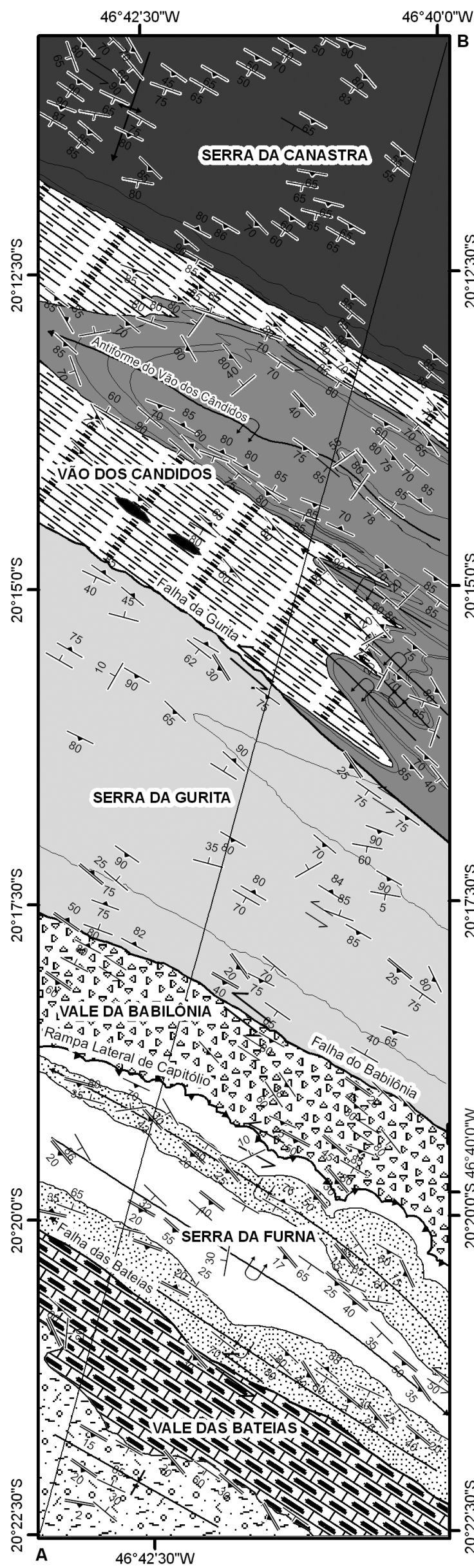

\begin{tabular}{|l}
\hline Legenda \\
DOMíNIO INTERNO \\
Subdomínio Bateias \\
Unidade Ba-2 Quartzito foliado branco a amarelado, com pouca muscovita. Esse \\
quartzito apresenta granulação mais grossa que os demais. \\
Unidade Ba-1 Muscovita xisto prateado com raras intercalaçöes de quartzito \\
micáceo.
\end{tabular}
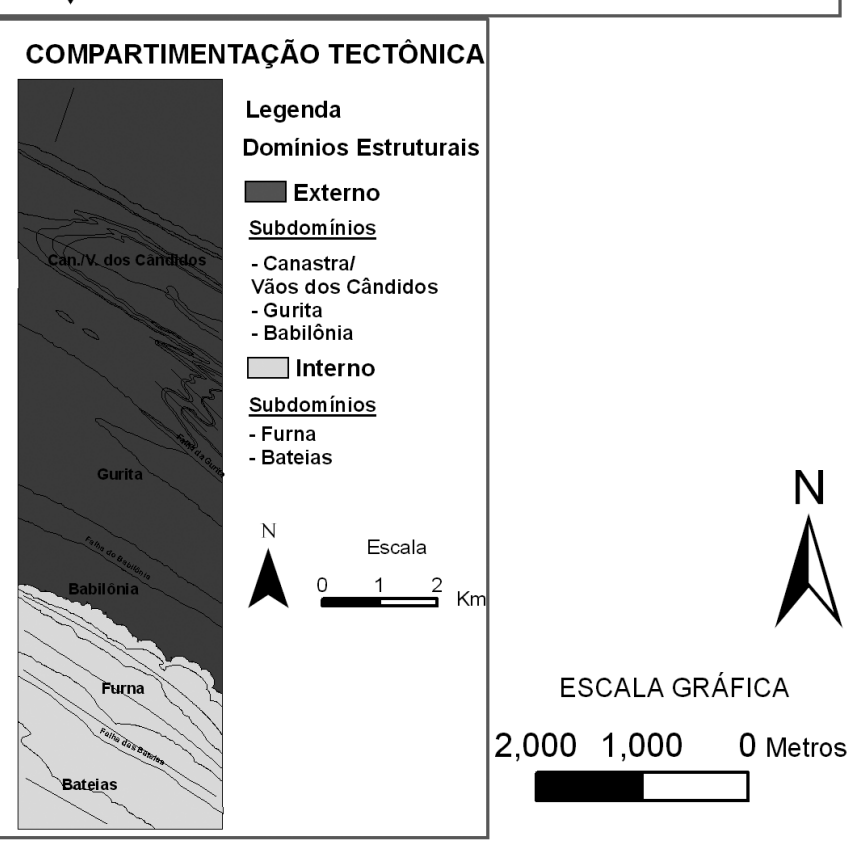

ESCALA GRÁFICA

$2,000 \quad 1,000 \quad 0$ Metros

Figura 4 - Mapa Geológico da área estudada (Modificado de Santos 2007). Detalhe: compartimentação tectônica adotada. 
pitólio (RLC), balizando a extensão para norte da $N P$. As rochas do DE são correlacionadas ao Grupo Canastra e ainda, uma mélange tectônica, que pode ter envolvido além de rochas dos domínios Interno e Externo, rochas atribuídas ao embasamento e ao Grupo Bambuí. Todas essas unidades são afetadas por uma zona de cisalhamento dúctil-rúptil subvertical, associada ao desenvolvimento da RLC. O DE é ainda subdividido em três subdomínios, Canastra/ Vão dos Cândidos, Gurita e Babilônia, separados por duas falhas oblíquas com forte componente direcional e mergulho de alto ângulo. As aqui denominadas de falhas correspondem, no sentido de Ramsay \& Huber (1983), às descontinuidades geradas dentro de um cinturão de cisalhamento desenvolvido em regime dúctil-rúptil.

O DI é representado por metassedimentos do Grupo Araxá, incluídos na $N P$, envolvidos em uma zona de cisalhamento com mergulho de baixo ângulo com sentido de transporte de topo para ESE, colocando as rochas do Grupo Araxá sobre o Grupo Canastra. Ele é subdividido em dois subdomínios (Furna e Bateias) através da Falha das Bateias.

Litoestratigrafia As unidades litológicas reconhecidas nos Domínios Interno e Externo são exibidas no Mapa Geológico da figura 4. Foram individualizadas cinco unidades litoestratigráficas no DE e quatro no DI.

As rochas que compõem essas unidades são basicamente metassedimentos psamíticos, psamo-pelíticos e pelíticos, representados por quartzito, quartzito micáceo (muscovita), quartzo xisto, muscovita xisto, albita-muscovita xisto e filito. A distinção entre as unidades apresentadas baseia-se principalmente nas proporções em que essas litologias se intercalam, ressaltando diferentes feições geomorfológicas.

Os metassedimentos do DE muitas vezes apresentam o contorno de grãos de quartzo sedimentares preservados, principalmente a norte da Serra da Gurita e também algumas feições sedimentares. Ocorrem ainda subordinadamente rochas metabásicas, encontradas somente no subdomínio Canastra/Vão dos Cândidos. O subdomínio Babilônia possivelmente representa uma mélange tectônica, formada durante o desenvolvimento da RLC e que envolveu, provavelmente, rochas dos Domínios Cratônico, Externo e Interno. Nessa mélange ocorrem, além das rochas já citadas, epidoto-albita-muscovita gnaisse e biotita-clorita-albita-muscovita gnaisse.

As rochas do DI apresentam os grãos de quartzo totalmente recristalizados e as feições sedimentares já apagadas pela soma de deformação e metamorfismo.

\section{Metamorfismo}

DOMÍNIO EXTERNO As paragêneses metamórficas reconhecidas no DE indicam que as rochas dos subdomínios Canastra/Vão dos Cândidos e Gurita foram metamorfisadas em fácies xisto verde, na zona da clorita, sob condições que podem atingir temperaturas pouco acima de $400^{\circ} \mathrm{C}$ (Yardley 1989). Não foram identificados minerais que permitissem avaliar a condição de pressão. Em geral as rochas da Faixa Brasília são atribuídas ao tipo
Barroviano de metamorfismo, de pressão intermediária, em função da presença de cianita em xistos dessa faixa.

As principais associações minerais observadas definem a foliação principal presente no $\operatorname{DE}\left(\mathrm{S}_{2}\right)$. Foi reconhecida uma paragênese pré-deformação principal, definindo uma foliação $\left(\mathrm{S}_{1}\right)$ tectônica, paralela ao bandamento composicional, entendido como a estratificação primária $\left(\mathrm{S}_{0}\right)$, formada por muscovita + opaco; essa paragênese também é estável na zona da clorita da fácies xisto verde, não devendo haver muita diferença nas condições de pressão e temperatura entre essas duas fases deformacionais.

Nas rochas do subdomínio Babilônia foram identificadas paragêneses minerais que apontam metamorfismo mínimo na zona da biotita da fácies xisto verde: albita + epidoto + muscovita; clorita + muscovita + epidoto + albita; biotita + muscovita + clorita + albita. E em um ponto foi encontrada granada. Apesar dessas paragêneses já estarem totalmente paralelizadas à foliação principal do DE $\left(\mathrm{S}_{2}\right)$, elas apresentam indícios de que estavam instáveis durante a formação dessa foliação: biotita alterada para titanita e clorita; a presença de epidoto + albita indicaria presença de um plagioclásio mais cálcico. Baseado nessas observações, interpretamos que as paragêneses que indicam graus mais elevados de metamorfismo, no mínimo na zona da biotita, são pré-deformação principal, e foram retrometamorfisadas durante o evento de deformação principal que afetou o DE.

DOMÍNIO INTERNO A paragênese mineral principal observada no DE é quartzo + muscovita; em um afloramento foi observada a paragênese: biotita + muscovita + quartzo.

Segundo Simões (1995a), a base da nappe de Passos, apresenta metamorfismo na fácies xisto verde, zona da biotita, indicando condições de temperatura que podem variar de $400^{\circ}$ a $450^{\circ} \mathrm{C}$. A ausência de biotita em grande parte das rochas estudadas nesse domínio deve ser reflexo apenas da composição das mesmas, desfavorável a formação desse mineral.

A foliação principal que ocorre no Domínio Interno $\left(\mathrm{S}_{3}\right)$, é marcada principalmente pela paragênese muscovita + quartzo. Como reconhecido por alguns autores (Zanardo 1992, Simões 1995a, Valeriano 1999, Luvizotto 2003), o auge metamórfico da nappe de Passos é relacionado a um evento pré/cedo deformação principal, então a paragênese biotita + muscovita está correlacionada a um evento anterior ao que gerou a $\mathrm{S}_{3}$.

Geologia Estrutural Inicialmente foi feita separadamente a caracterização estrutural do DE e DI. Em seguida foi estabelecida uma correlação entre as estruturas presentes nos dois domínios com base nos critérios de superposição de estruturas, que foram agrupadas em 3 fases de deformação principais $\left(\mathrm{D}_{1}, \mathrm{D}_{2}\right.$ e $\left.\mathrm{D}_{3}\right)$, e estruturas tardias.

As estruturas observadas desenvolveram-se de forma heterogênea ao longo da área estudada. A fase $\mathrm{D}_{2}$ é marcante no DE, notada principalmente por uma foliação $\mathrm{S}_{2}$, de direção NW-SE, com mergulhos íngremes principalmente para SW, aparecendo sobreposta 
por estruturas da fase $\mathrm{D}_{3}$, principalmente próximo ao contato entre os dois domínios. A fase $\mathrm{D}_{3}$ é marcante no DI, caracterizada por uma foliação $\mathrm{S}_{3}$, com mergulhos suaves para $\mathrm{SW}$, que mascara as estruturas relacionadas à fase $\mathrm{D}_{2}$ no $\mathrm{DI}$, principalmente dobras normais abertas a fechadas, com desenvolvimento incipiente da foliação $\mathrm{S}_{2}$ (Fig. 5 e Fig. 6)

Entendemos que a fase $\mathrm{D}_{2}$ colocou lado a lado os Domínios Interno e Externo e a partir desse momento começaram a compartilhar de uma mesma história geológica. As estruturas pré- $\mathrm{D}_{2}$ relacionadas a cada Domínio, apesar de estarem agrupadas em uma fase $\mathrm{D}_{1}$, foram geradas por processos geológicos distintos e provavelmente em diferentes épocas.

FASE $D, \quad$ A principal estrutura desenvolvida antes da fase $\mathrm{D}_{2}$ em ambos os domínios corresponde a uma xistosidade $\left(\mathrm{S}_{1}\right)$ paralela a um bandamento composicional. Esse bandamento composicional é marcado, principalmente, pela intercalação de níveis (milimétricos a mé-

\section{PADRÃO ESTRUTURAL DE x DI}

\section{Domínio Externo}

Padrão Geral - DE

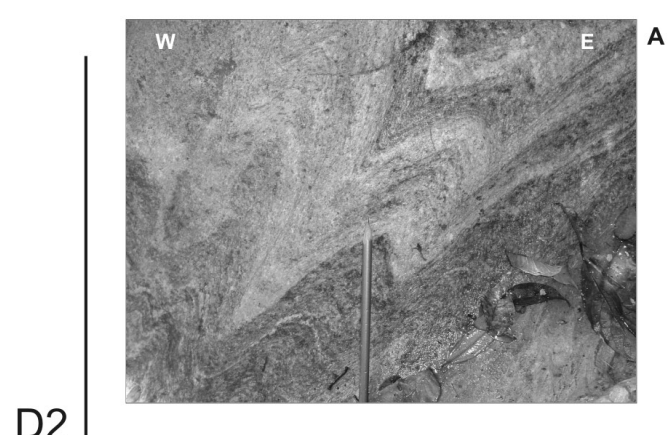

D2

D3

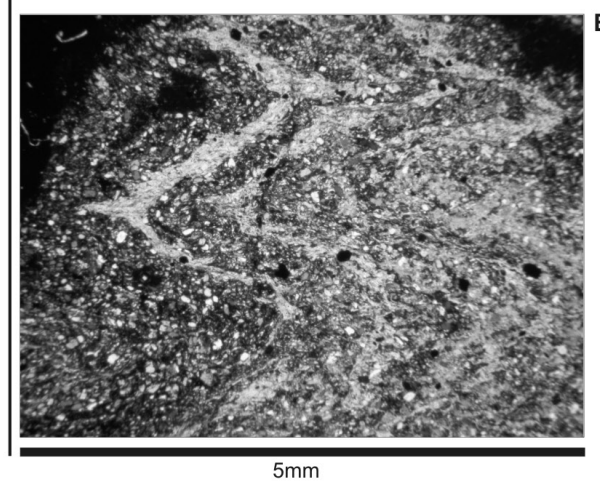

\section{Domínio Interno}
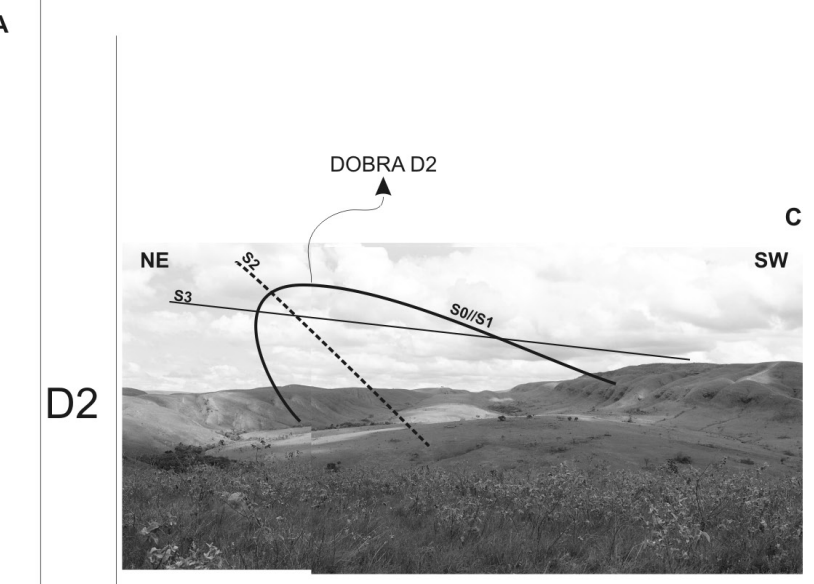

Padrão Geral - DI

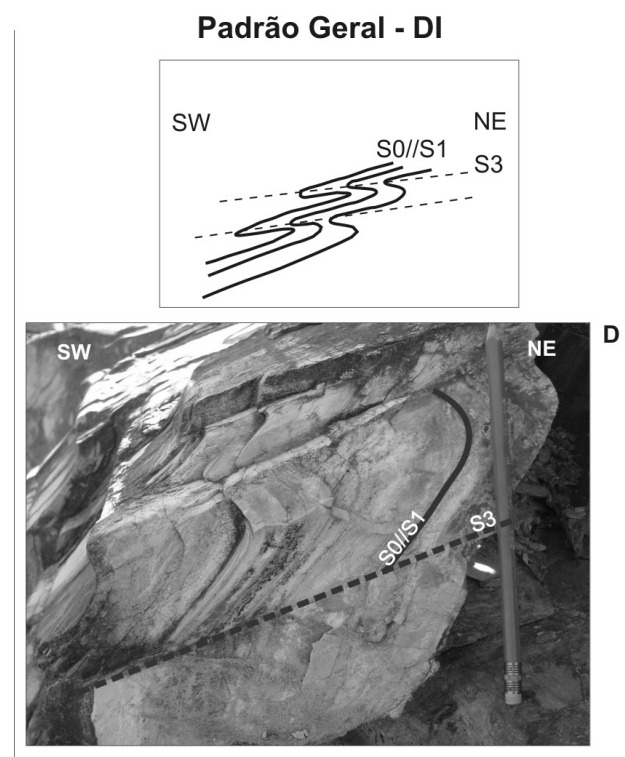

Figura 5 - Esquema comparativo entre as estruturas desenvolvidas no DE e no DI, com o padrão geral reconhecido para cada domínio. 


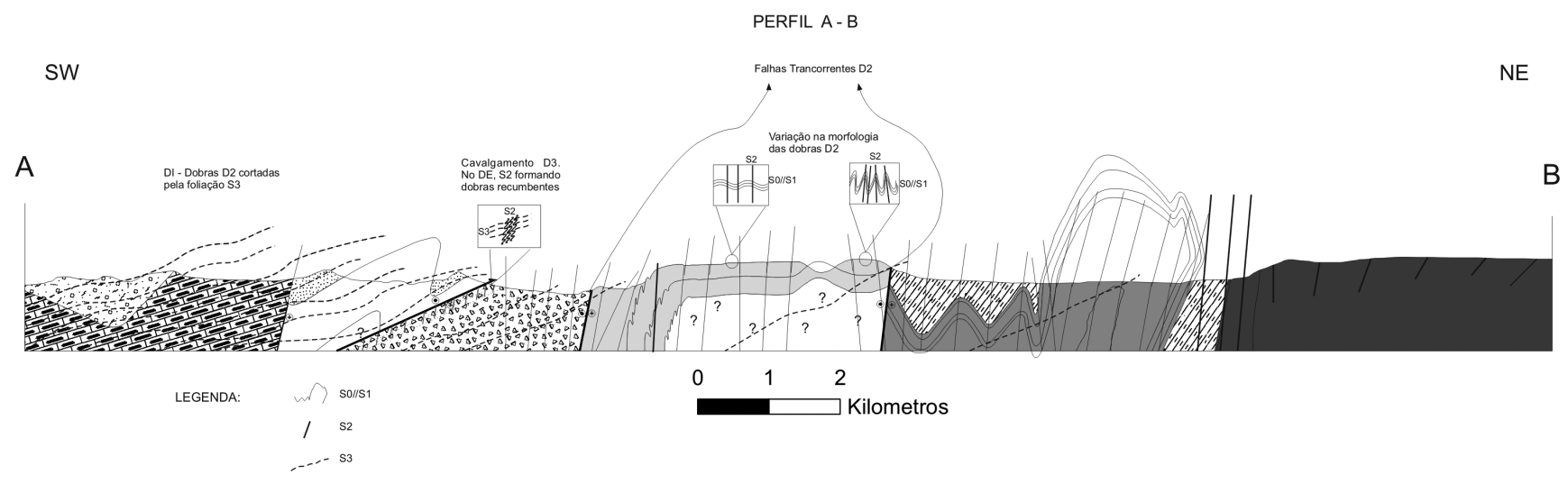

Figura 6 - Perfil Geológico. Legenda das unidades, mesma do Mapa geológico, figura 4.

tricos) de composição quartzítica a xistosa e, é interpretado como a preservação de camadas originalmente sedimentares de diferentes composições $\left(\mathrm{S}_{0}\right)$, outra evidência de $\mathrm{S}_{0}$ são níveis milimétricos mais ricos em opacos e minerais pesados (turmalina e zircão), vistos em alguns quartzitos.

A foliação $S_{1}$ é formada principalmente pela orientação preferencial de micas (muscovita) e opacos. No DI, em poucos locais onde a litologia é favorável, notamos a presença de biotita.

FASE $\mathrm{D}_{2}$ Essa fase é responsável pela geração da estrutura mais marcante no DE, uma foliação, $S_{2}$. No DI essa fase é pouco marcante, notada principalmente pela presença de dobras quilométricas abertas a fechadas, com desenvolvimento local de foliação.

A xistosidade/clivagem de crenulação $S_{2}$ é marcada, pela forma alongada de cristais de quartzo, além da orientação de micas: muscovita e clorita. Vista em lâmina essa foliação apresenta simetria do tipo S-C. A orientação principal dessa estrutura é NW-SE (310$330)$, apresentando mergulho íngreme $\left(60^{\circ}\right.$ a $\left.90^{\circ}\right)$, preferencialmente para SW (Fig. 7).

A essa fase associa-se também o desenvolvimento de um conjunto de dobras que variam de escala milimétrica a quilométrica. A superfície que se encontra dobrada corresponde a um bandamento composicional reconhecido como sendo o plano de $\mathrm{S}_{0} / / \mathrm{S}_{1}$. São dobras
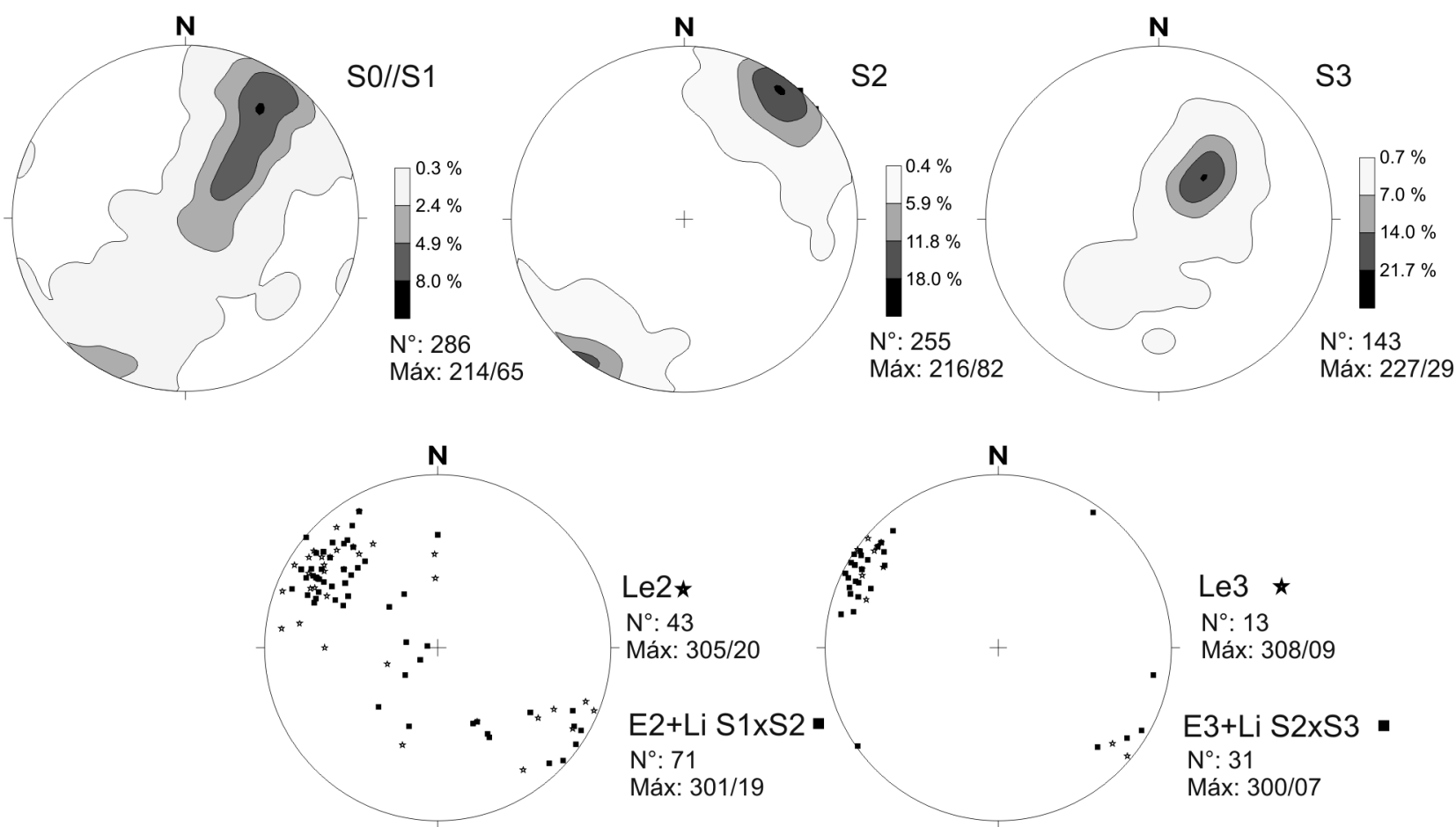

Figura 7 - Estereogramas (concentração de pólos) mostrando as atitudes preferenciais dos planos $S_{d} / l$ $S_{1}, S_{2}$ e $S_{3}$; além das direções das lineações de estiramento ( $\left.L_{2} e_{2} L e_{3}\right)$, o eixo das dobras e lineações de intersecção para as fases $D_{2}$ e $D_{3}$. 
isoclinais a abertas, em alguns locais intrafoliais com $\mathrm{S}_{2}$ em posição plano axial. Onde as dobras são muito apertadas $\mathrm{S}_{2}$ se paraleliza a $\mathrm{S}_{0} / / \mathrm{S}_{1}$, formando a foliação composta $\mathrm{S}_{0} / / \mathrm{S}_{1} / / \mathrm{S}_{2}$. Os eixos dessas dobras têm caimento para NW com atitude principal entre $300-310 / 10-30^{\circ}$.

Sobre o plano $\mathrm{S}_{2}$ desenvolveu-se uma lineação de estiramento/mineral marcada principalmente pela forma alongada de cristais de quartzo e o crescimento orientado de micas e turmalina. Essa lineação é, em geral, paralela ao eixo das dobras descritas para essa fase $\left(300-310 / 4-30^{\circ}\right)$, exceto no topo da Serra da Canastra, onde essas lineações possuem caimentos íngremes para SSW, estando em posição dip.

Todos indicadores cinemáticos encontrados indicam sentido de movimento sinistral para a componente direcional, com alçamento dos blocos à SW. Foram observados tension gashes em quartzitos da unidade CVC1 (140-150/80-90) associados à foliação 200/85. No subdomínio Babilônia foram vistos sigmóides de quartzo e, principalmente próximo a Falha da Babilônia, um plano de foliação oblíqua (N180/85) à foliação principal $\left(\mathrm{S}_{2}\right)$, interpretado como bandas de cisalhamento $\mathrm{C}^{\prime}$, sin- $\mathrm{D}_{2}$. Em descrições microscópicas foi observada recristalização oblíqua de cristais de quartzo (CVC-1 e GU-1), mica fishes de muscovita (CVC-1) e sombras de pressão assimétricas, principalmente em piritas (Ba-1).

A intersecção de $S_{2}$ com o plano $S_{0} / / S_{1}$ forma uma lineação de intersecção e gera estruturas em lápis.

Todas as falhas maiores que controlam a compartimentação tectônica apresentada, com exceção da que coloca os domínios Interno e Externo em contato, também são correlacionadas à fase $\mathrm{D}_{2}$. Essas falhas são de difícil distinção em campo e foram inferidas com base na observação de truncamento de camadas.

Os dados da cartografia geológica e as observações diretas no campo mostram que estas falhas têm mergulhos íngremes, próximos aos dos planos $\mathrm{S}_{2}$. $\mathrm{O}$ sentido de movimento é considerado sinistral, como mostrado pelos indicadores cinemáticos observados.

$F A S E D_{3} \quad$ Essa fase de deformação originou dobras subrecumbentes que afetam as estruturas previamente formadas, gerando foliação $\left(\mathrm{S}_{3}\right)$ em posição plano axial a essas dobras. Essa é a fase de deformação mais evidente no DI.

As estruturas relacionadas a essa fase são menos penetrativas no $\mathrm{DE}$, sendo raras no subdomínio $\mathrm{Ca}-$ nastra/Vão dos Cândidos e aumentando de freqüência em direção a sul, identificadas com maior constância foliações de baixo ângulo e dobras subrecumbentes a partir do subdomínio Gurita, e se tornando comum nas rochas do subdomínio Babilônia.

A xistosidade/clivagem de crenulação $\mathrm{S}_{3}$ é marcada principalmente pela forma alongada dos cristais de quartzo, e também pela orientação de muscovita. Essa foliação possui direção NW-SE (N310-330), mergulhando entre 20 e 60 graus pra SW. Em alguns locais em que essa foliação mergulha para NE, notamos claramente ser efeito de refração da clivagem, mas em outros deve ser causado por dobramentos posteriores (Fig. 7).

Ligadas a essa fase de deformação ocorrem dobras subrecumbentes centimétricas a decimétricas, abertas a isoclinais. Na borda norte da Serra da Gurita foram observadas dobras de escala métrica que podem ser relacionadas a essa fase. $\mathrm{O}$ eixo dessas dobras tem caimentos suaves $\left(0-10^{\circ}\right)$ para NW (300-320). A superfície dobrada corresponde a $\mathrm{S}_{0} / / \mathrm{S}_{1} / / \mathrm{S}_{2}$ (Fig. 7).

Sobre essa foliação desenvolveu-se uma lineação mineral/estiramento, observada somente no DI, marcada pelo crescimento orientado de micas e o estiramento de cristais de quartzo. Essa lineação possui direção paralela ao eixo das dobras geradas nessa fase, com o máximo estando em torno de 308/09 (Fig. 7).

Foram observados indicadores cinemáticos apenas em seções delgadas, correspondendo à mica fishes indicando direção do cisalhamento como de topo para SE. A intersecção dessa foliação com o $\mathrm{S}_{0} / / \mathrm{S}_{1} / / \mathrm{S}_{2}$ gera uma lineação de intersecção bem evidente principalmente em pontos onde afloram quartzitos com mergulhos íngremes no DI.

O contato entre os Domínios Interno e Externo é marcado por uma falha de baixo ângulo, paralela a $S_{3}$. Por isso a correlacionamos com a colocação do DI sobre o DE. As evidências para isso são observações em perfis de drenagens que cortam essa falha, que mostra claramente o intenso desenvolvimento da foliação $S_{3}$ nas rochas do DE, próximo ao contato com o DI, mas ainda sendo possível reconhecer $\mathrm{S}_{2}$ dobrado (Fig. 5-B).

FASES TARDIAS Foram observadas dobras abertas e do tipo kink com eixos com direções SSW-SW e NW$\mathrm{SE}$, aonde a superfície dobrada correspondem a $\mathrm{S}_{2}$ no DE e $\mathrm{S}_{3}$ no DI, representando dois eventos deformacionais tardios na história tectônica desta área.

Os eixos dessas dobras possuem caimentos variados, reflexo da atitude original do plano que está sendo dobrado. Os eixos das dobras possuem direção 190230 com caimento de $65-80^{\circ}$ no DE e subhorizontal no DI. Na Serra da Canastra foi mapeado um antiforme relacionado a essa fase.

As dobras com eixo com caimento para NWSE possuem atitude preferencial 126/2 e 305/5 no DI e mergulhos mais íngremes no DE

ANÁLISE CINEMÁTICA Na área estudada foram reconhecidas 3 fases principais de deformação e duas tardias, desenvolvidas durante a Orogênese Brasiliana.

Não foram encontrados indicadores cinemáticos nem lineações relacionados à fase $\mathrm{D}_{1}$, provavelmente obliterados pelas fases posteriores. Como interpretamos que a fase $\mathrm{D}_{2}$ é responsável pela formação da rampa lateral que coloca os Domínios Interno e Externo lado a lado, as estruturas pré- $\mathrm{D}_{2}$ geradas devem representar histórias geológicas distintas, conforme sugere a diferença de grau metamórfico entre os dois domínios.

No DI a fase $\mathrm{D}_{1}$ é reconhecida principalmente pela foliação $S_{1}$, e deve ser reflexo de processos termotectônicos responsáveis pela condução das rochas do Grupo Araxá a grandes profundidades, gerando as condições de auge metamórfico; e do processo inicial de exumação da nappe. (Simões 1995a, Valeriano 1999, Silva 2003). 
Desta forma, $S_{1}$ deve ser um tipo de foliação composta. No DE, a fase $\mathrm{D}_{1}$ estaria relacionada a movimentos tangenciais, responsáveis pela colocação das rochas do Grupo Canastra sobre o Domínio Cratônico, sendo posteriormente cavalgado pelas rochas do Domínio Interno.

Formação da Rampa Lateral de Capitólio Para o entendimento da formação e desenvolvimento da RLC são necessárias correlações regionais para melhor compreensão da idéia de progressividade e simultaneidade entre a formação das estruturas aqui relacionadas às fases $\mathrm{D}_{2} \mathrm{e} \mathrm{D}_{3}$.

$\mathrm{Na}$ área estudada, a fase $\mathrm{D}_{2}$ é marcante no $\mathrm{DE}$ e aparece mais discretamente no DI. A presença de uma forte lineação de estiramento subhorizontal nos planos de $S_{2}$, com direção NW-SE, evidencia que as estruturas atribuídas à fase $\mathrm{D}_{2}$ foram geradas em uma zona de cisalhamento subvertical, marcada principalmente por movimentos direcionais. Os indicadores cinemáticos observados revelam movimentos sinistrais. As dobras relacionadas a essa fase se encontram com os eixos paralelos à lineação de estiramento, provavelmente por terem sido rotacionadas durante o desenvolvimento dessa zona de cisalhamento.

A tabela 1 correlaciona as estruturas encontradas na área estudada com os trabalhos de Simões (1995a e b) e Silva (2003), realizados em áreas adjacentes a Sul e a Norte, respectivamente, a atualmente estudada.

Ao contrário da fase $\mathrm{D}_{2}$, a fase $\mathrm{D}_{3}$ é mais marcante no DI e pouco expressiva no DE. No plano da foliação
$\mathrm{S}_{3}$ desenvolveu-se uma lineação de estiramento de direção NW-SE e os indicadores cinemáticos evidenciam transporte de topo para SE, observados somente no DI.

As estruturas relacionadas a essa fase foram também observadas por Simões (1995a) e Silva (2003). Esses autores tratam essa fase como o evento de deformação principal que atuou na área e afetam todas as estruturas previamente formadas. Simões (1995a) e Valeriano (1999), também atribuem a essa fase a colocação da $N P$ na posição em que se encontra atualmente.

$\mathrm{Na}$ área estudada observamos a mesma relação de superposição de estruturas descrita pelos autores acima citados, ficando clara essa relação no contato entre os Domínios Externo e Interno, marcado por um plano de falha que mergulha com baixo ângulo e se sobrepõe à foliação $S_{2}$, subvertical, gerando uma zona de cisalhamento marcada por dobras subrecumbentes $\mathrm{D}_{3}$ (Fig. 6).

Os dados expostos acima levantam uma indagação: se encontramos as estruturas relacionadas à fase $\mathrm{D}_{2}$ em ambos os domínios, por que no DE ela é tão marcante, e se torna bruscamente pouco acentuada no DI? Esperaríamos que a penetratividade dessas estruturas fosse desenvolvida igualmente em ambos os domínios, diminuindo conforme nos afastássemos do plano principal da falha, mas isso não acontece.

A partir dessa suposição elaboramos um modelo para a morfologia inicial da Rampa Lateral de Capitólio.

Tabela 1 - Correlação entre os conjuntos de estruturas relacionadas às fases de deformação, descritas no atual trabalho (segunda coluna) e por Simões (1995) e Silva (2003).

\begin{tabular}{|c|c|c|c|c|c|}
\hline \multicolumn{2}{|l|}{ Sul } & \multicolumn{3}{|c|}{ DOMÍNIO EXTERNO } & Norte \\
\hline \multicolumn{2}{|c|}{ Simões 1995a } & \multicolumn{2}{|c|}{ PRESENTE TRABALHO } & \multicolumn{2}{|c|}{ Silva 2003} \\
\hline $\mathrm{D}_{1}$ & $\begin{array}{l}\text { Dobras isoclinais recumbentes, eixos N-S; } \\
\text { clivagem ardosiana } S_{1} \text { subhorizontal. }\end{array}$ & $\mathrm{D}_{1}$ & Xistosidade $\mathrm{S}_{1}$ & $\mathrm{D}_{1}$ & Xistosidade $\mathrm{S}_{1}$ \\
\hline \multirow[t]{2}{*}{$\begin{array}{l}\mathrm{D}_{2} \\
\text { Precoce }\end{array}$} & \multirow{2}{*}{$\begin{array}{l}\text { Auge metamórfico, dobras apertadas a } \\
\text { isoclinais (e em bainha) recumbentes, } \\
\text { eixos E-W a NW; clivagem / xistosidade } \\
\text { de crenulação } \mathrm{S}_{2} \text {; lineação mineral/ } \\
\text { estiramento paralela ao eixos das dobras. } \\
\text { Na parte norte da Nappe de Passos dobras } \\
\text { de escala até quilométrica, com plano } \\
\text { axial subvertical. }\end{array}$} & \multirow[t]{2}{*}{$\mathrm{D}_{2}$} & \multirow{2}{*}{$\begin{array}{l}\text { DE: Foliação subvertical de direção NW- } \\
\text { SE Dobras normais isoclinais a abertas } \\
\text { com eixo de direção NW-SE. Paralelo } \\
\text { ao eixo das dobras lineação mineral/ } \\
\text { estiramento. Sentido de transporte para } \\
\text { SE. } \\
\text { DI: Dobras normais abertas a fechadas } \\
\text { com formação de foliação plano axial } \\
\text { localizada. }\end{array}$} & $\mathrm{D}_{2}$ & $\begin{array}{l}\text { Auge metamórfico; dobras } \\
\text { apertadas, verticais, eixos } \\
\text { variando de NW-SE, E-W a } \\
\mathrm{N}-\mathrm{S} \text {; xistosidade/ clivagem de } \\
\text { crenulação } \mathrm{S}_{2} \text {; lineação mineral/ } \\
\text { estiramento; transporte tectônico } \\
\text { para SE. }\end{array}$ \\
\hline & & & & $\mathrm{D}_{3}$ & $\begin{array}{l}\text { Dobras abertas, normais, com } \\
\text { plano axial vertical. Eixo NW-SE, } \\
\text { localmente clivagem ardosiana } \mathrm{S}_{3} \text {. }\end{array}$ \\
\hline $\begin{array}{l}\mathrm{D}_{2} \\
\text { Tardio }\end{array}$ & $\begin{array}{l}\text { Exumação e colocação da Nappe de } \\
\text { Passos e demais nappes internas sobre o } \\
\text { Domínio Externo; transporte tectônico } \\
\text { para SE; retrometamorfismo. }\end{array}$ & $\mathrm{D}_{3}$ & $\begin{array}{l}\text { DE: Foliação subhorizotal incipiente, } \\
\text { em posição plano axial de dobras } \\
\text { subrecumbentes, formadas principalmen- } \\
\text { te na interface DI - DE. } \\
\text { DI: Foliação de direção NW-SE, com } \\
\text { mergulho principalmente para SW. } \\
\text { Dobras subrecumbentes com eixos // a } \\
\text { lineação mineral/estiramento (NW-SE). } \\
\text { Transporte tectônico para SE. }\end{array}$ & $\mathrm{D}_{4}$ & $\begin{array}{l}\text { Dobras apertadas a isoclinais, } \\
\text { inclinadas a recumbentes, eixos } \\
\text { NW-SE a E-W; clivagem de } \\
\text { crenulação } \mathrm{S}_{4} \text {; lineção mineral/ } \\
\text { estiramento, paralela ao eixo das } \\
\text { dobras; transporte em direção a } \\
\text { SE. }\end{array}$ \\
\hline $\mathrm{D}_{3}$ & $\begin{array}{l}\text { Dobras suaves a abertas com eixos WNW; } \\
\text { falhas subverticais associadas. }\end{array}$ & $\mathrm{D}_{4}$ & $\begin{array}{l}\text { Kinks e dobras abertas com eixo NW. } \\
\text { Formação de clivagem de crenulação } \\
\text { esporádica. }\end{array}$ & $\mathrm{D}_{5}$ & $\begin{array}{l}\text { Dobras suaves a abertas com eixos } \\
\text { NW-SE; zona de cisalhamento } \\
\text { subverticais associadas. }\end{array}$ \\
\hline $\mathrm{D}_{4}$ & $\begin{array}{l}\text { Dobras angulares empinadas, crenulações } \\
\text { e kinks com eixos N-S; falhas associadas. }\end{array}$ & $\mathrm{D}_{5}$ & Kinks e dobras abertas com eixo SSW & $\mathrm{D}_{6}$ & $\begin{array}{l}\text { Dobras suaves a abertas com } \\
\text { eixo N-S; falhas subverticais } \\
\text { associadas. }\end{array}$ \\
\hline
\end{tabular}


Reconstrução dos elipsóides de deformação das fases $\boldsymbol{D}_{2} \boldsymbol{e} \boldsymbol{D}_{3} \quad$ Na reconstituição dos eixos do elipsóide de deformação das fases $\mathrm{D}_{2}$ e $\mathrm{D}_{3}$ consideramos a lineação de estiramento como paralela ao eixo X, o pólo da foliação gerada como paralelo ao eixo $\mathrm{Z}$ e o eixo $\mathrm{Y}$ estando a $90^{\circ}$ de ambos.

Observando a direção dos eixos dos elipsóides de deformação estabelecidos para as fases $\mathrm{D}_{2}$ e $\mathrm{D}_{3}$ (Fig. 8 ), vemos que as lineações possuem atitudes muito semelhantes, estão subhorizontais e em posição direcional. Mas comparando as atitudes de $\mathrm{Z}$ e $\mathrm{Y}$ vemos que elas variam: o eixo $Z$ está subhorizontal na Fase $D_{2}$ e com mergulho mais íngreme na Fase $\mathrm{D}_{3}$, e conseqüentemente, posições simétricas para o eixo Y.

Como as duas fases apresentam a mesma direção do eixo X, é provável que tenham evoluído de forma progressiva dentro de um mesmo campo de esforço.

Para identificarmos o sentido de transporte/ cisalhamento, temos que reconhecer o vetor de vorticidade. A análise das seções delgadas mostrou para a maioria dos casos, o vetor de vorticidade como paralelo a subparalelo ao eixo Y (Santos 2007), caracterizando uma zona de cisalhamento do tipo Y (Passchier 1998).

Com isso identificamos a direção de transporte como subparalela ao eixo X (316/22) e o sentido para $\mathrm{SE}$, definido através dos indicadores cinemáticos. Essa direção de transporte, poderia ser gerada através de uma compressão tangencial $\left(\sigma_{1}\right) \mathrm{NW}-\mathrm{SE}$, ou uma compressão subhorizontal WNW-ESE.

Desenvolvimento das fases $\mathrm{D}_{2}$ e $\mathrm{D}_{3} \quad$ Considerando os elipsóides de deformação, o contexto tectônico regional e as estruturas mapeadas, a formação das estruturas relativas às fases $\mathrm{D}_{2}$ e $\mathrm{D}_{3}$ podem ser explicadas por um modelo considerando dois estágios:

PRIMEIRO ESTÁGIO O estágio inicial de desenvolvimento da RLC estaria ligado à fase inicial de colocação da $N P$. No DI desenvolviam-se simultaneamente estruturas com padrão das Fases $\mathrm{D}_{2}$ e $\mathrm{D}_{3}$, dependendo da posição em que se encontravam. Na parte central da nappe formavamse estruturas geometricamente semelhantes à fase $\mathrm{D}_{3}, \mathrm{em}$ posição de patamar; o limite entre os domínios Interno e Externo seria balizado por uma zona de cisalhamento vertical (rampa lateral) em que se desenvolviam estruturas análogas a fase $\mathrm{D}_{2}$, em ambos os domínios.

Não conseguimos identificar com clareza como seria a transição, no Domínio Interno, entre os sítios onde se desenvolviam foliações de baixo ângulo e alto ângulo. Podemos aventar duas possibilidades.

Na primeira, como é apresentado por alguns autores (Passchier 1998 e 1997, Fossen \& Tikoff 1998) (Fig. 3), poderíamos estar lidando com uma zona de cisalhamento com constrição lateral (Fig. 9A). Nesse caso, teríamos as rochas da nappe de Passos sendo comprimidas contra a parede da rampa lateral até o ponto em que o eixo $\mathrm{Z}$ do elipsóide de deformação passasse da posição subvertical para a horizontal. A partir desse ponto teríamos os eixos $\mathrm{X}$ e $\mathrm{Y}$ contidos num plano vertical, representado pela foliação. Nos termos de tipos de zonas de cisalhamento (Passchier 1998) estaríamos gradando de uma zona de cisalhamento tipo Y para uma zona de cisalhamento do tipo Z. Assim, continuaríamos com o eixo de vorticidade mergulhando com ângulo suave, mas agora paralelo ao eixo Z, o que implicaria em encontrarmos indicadores cinemáticos em cortes paralelos ao plano da foliação.

A segunda hipótese para explicar como se dá a transição de baixo ângulo para alto ângulo, baseia-se na rotação do eixo de vorticidade (Fig. 9B).

Se os estratos sedimentares carregados na $N P$ se moldam segundo um grande sinformal, poderíamos supor que o plano de cisalhamento se mantenha subparalelo ao $\mathrm{S}_{0}$. Dessa maneira o eixo de vorticidade rotacionaria em torno do eixo $\mathrm{X}$, da posição subhorizontal para a posição vertical, diferentemente da hipótese anterior em que o eixo de vorticidade mantinha-se na posição subhorizontal. Nesse modelo em vez de se passar de uma zona de cisalhamento tipo Y para uma do tipo Z, haveria apenas uma zona de cisalhamento do tipo Y, passando de subhorizontal para subvertical, formando foliações gradativamente
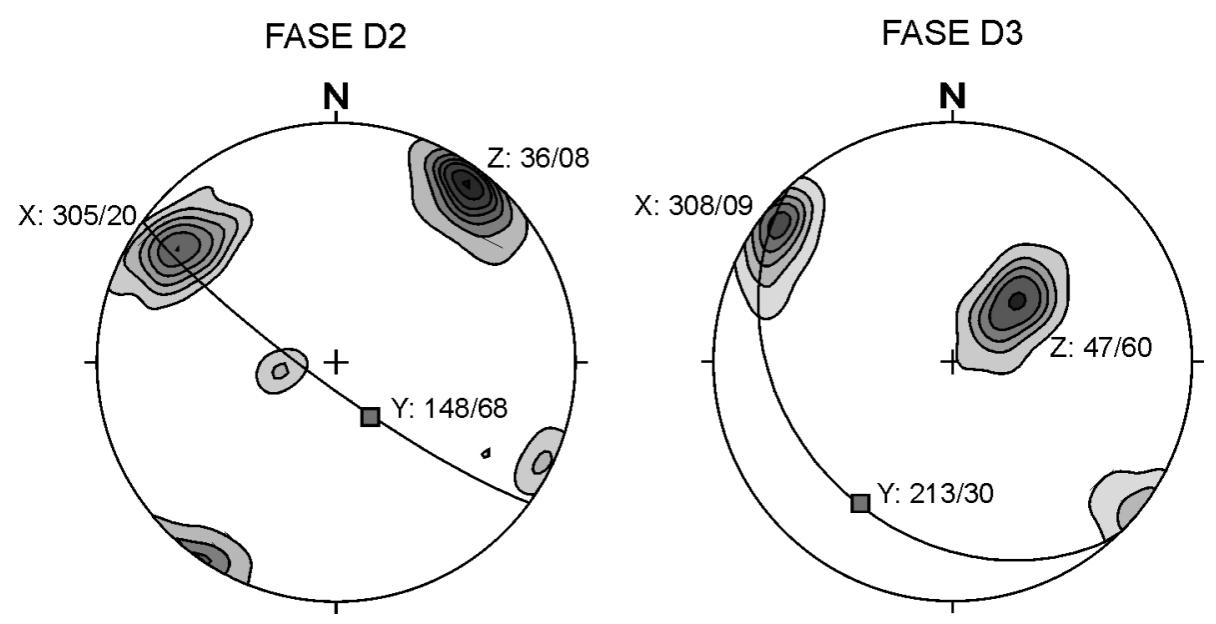

Figura 8 - Estereogramas mostrando os eixos dos elipsóides de deformação relacionados às fases $D_{2}$ e $D_{3}$ (válido para os dois domínios). 

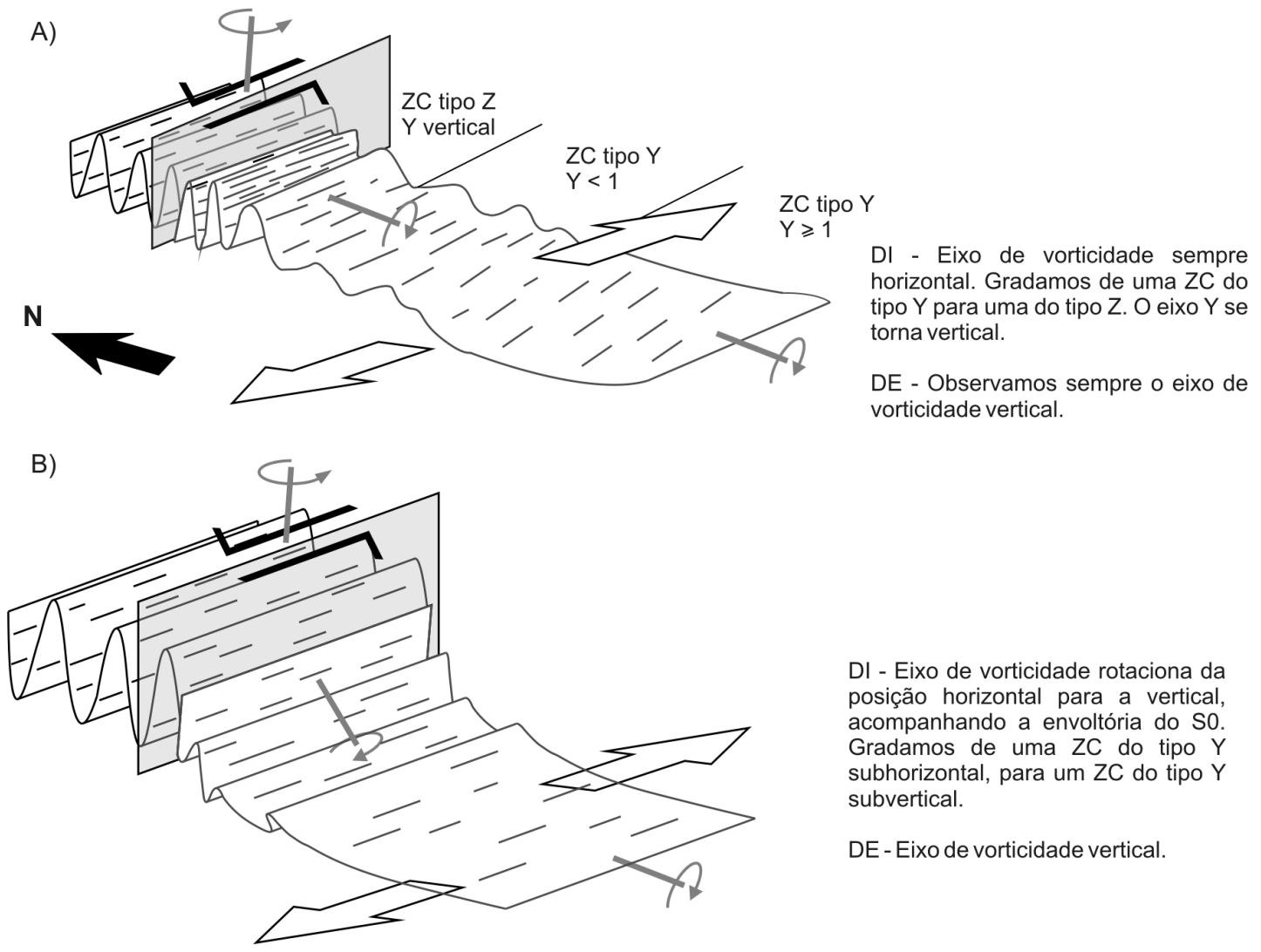

DI - Eixo de vorticidade rotaciona da posição horizontal para a vertical, acompanhando a envoltória do SO. Gradamos de uma ZC do tipo $Y$ subhorizontal, para um ZC do tipo $Y$ subvertical.

DE - Eixo de vorticidade vertical.

Figura 9 - Modelos das prováveis hipóteses para o desenvolvimento inicial da Fase $D_{2}$, relacionada à geometria inicial do limite norte nappe de Passos (explicação detalhada no texto). Setas vazadas: sentido de cisalhamento subhorizontal. Meias-setas em preto sentido de cisalhamento vertical. Traços cinzas com seta curva: eixo de vorticidade e sentido de rotação.

mais íngremes, até se encontrar em posição subvertical.

Apesar de serem escassas as observações da foliação vertical no DI, na qual teríamos que tentar identificar o vetor de vorticidade, entendemos que a hipótese de rotação do eixo de vorticidade é mais plausível, por comparação com o DE, que possui o eixo de vorticidade subvertical.

O eixo de vorticidade sempre se mantém em posição subvertical. Em grande parte do DE temos estiramento principal na subhorizontal e o eixo Y paralelo ao vetor de vorticidade caracterizando uma zona de cisalhamento do tipo Y.

SEGUNDO ESTÁGIO O estágio posterior de desenvolvimento da RLC estaria ligado à estruturas com afinidade a Fase $\mathrm{D}_{3}$.

Entendemos que, com a continuidade da colocação da $N P$, a deformação/deslocamento ao longo da RLC foi progressivamente diminuindo até o ponto em que a deformação começou a ser absorvida por planos de baixo ângulo em toda a nappe.

Como, próximo à rampa lateral, as rochas do DI se encontravam dobradas, essa deformação era acomodada com maior dificuldade e, por essa razão, possivelmente aproveitando um plano pré-existente na parte mais interna da nappe, as rochas se romperam e caval- garam as rochas do DE, gerando estruturas que sobrepuseram todas as previamente formadas.

Como citado por alguns autores (Pohn 2000), deve ocorrer em nappes com paredes convergentes uma constrição lateral por diminuição de volume em direção ao sentido de transporte. Nesse tipo de nappe uma componente de encurtamento perpendicular ao sentido de transporte, que poderia resultar em escape lateral perpendicular à rampa lateral/oblíqua.

Se ocorreu esse tipo de movimento esperaríamos encontrar lineações com direção entre N-S e NNE-SSW, nos planos $\mathrm{S}_{3}$. Mas as lineações observadas possuem direção NW-SE, indicando transporte de topo para SE.

Dessa maneira, o cavalgamento que marca o contato entre os Domínios Interno e Externo, deve ter funcionado como uma rampa oblíqua com mergulho suave, que truncou a rampa original mais íngreme, com sentido de transporte aproximadamente para ESE (Fig. 10).

Esse cavalgamento alçou as rochas do DI sobre o DE. Provavelmente parte dessa frente de empurrão já foi erodida, pois o que se encontra exposto hoje na área mapeada são rochas que se encontravam na parte mais interna da nappe em contato com as rochas do DE. Esse fato poderia explicar porque não observarmos os planos $\mathrm{S}_{2}$ bem desenvolvidos no DI. 

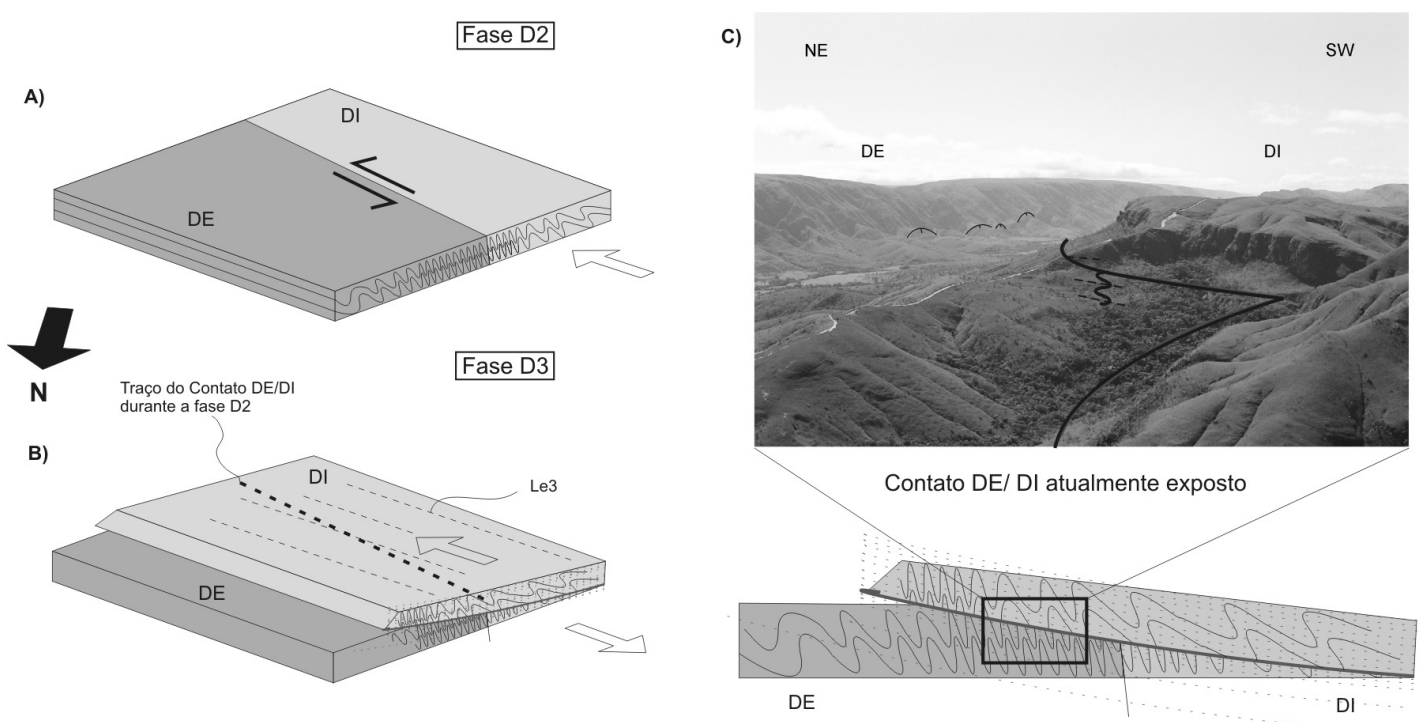

Figura 10 - A) Estágio inicial do desenvolvimento da RLC. B) Sobreposição da Rampa Lateral íngreme por um plano de cavalgamento oblíquo com mergulho suave, colocando lado a lado partes mais interna da nappe com o DE. C) Contato atual DE/DI, marcado por uma falha de baixo ângulo. Ao fundo borda sul da Serra da Gurita, onde observamos foliação vertical relacionada à fase $D_{2}$. Próximo ao contato a foliação vertical se encontra dobrada, com $\mathrm{S}_{3}$ em posição plano axial.

CONCLUSÕES Caracterizamos diferentes padrões estruturais desenvolvidos ao longo do contato entre Domínios Interno e Externo da FBM no contexto da nappe de Passos. Esse padrão estrutural não reflete o padrão geral descrito para esses domínios ao longo de toda FBM, restringindo-se ao contexto da RLC.

O DE é marcado principalmente pelo forte desenvolvimento de uma foliação subvertical, de direção NW$\mathrm{SE}$, que se encontra em posição plano axial de dobras que variam de abertas a isoclinais. No DI observamos uma foliação com mergulho suave $\left(5-30^{\circ}\right)$ principalmente para SW, plano axial de dobras subrecumbentes.

Analisando em detalhe essas estruturas notamos uma zona de interferência entre os dois padrões descritos, refletidos no DI por dobras com plano axial vertical sem foliação desenvolvida, cortadas pelas foliações de baixo ângulo; e no DE, pela foliação subvertical formar localmente dobras subrecumbentes, com desenvolvimento de foliação plano axial principalmente próximo ao contato entre esses dois Domínios.

O contato entre os Domínios Interno e Externo foi caracterizado como de baixo ângulo, identificando-se que as estruturas de baixo ângulo sobrepõem-se as de alto ângulo. Dessa maneira entendemos que na fase inicial de exumação da $N P$, iniciou-se o desenvolvimento da Rampa Lateral de Capitólio. O limite entre os Domínios Interno e Externo era marcado por uma rampa la- teral íngreme e, nesse contexto, eram geradas estruturas com afinidade ao padrão estrutural descrito para o $\mathrm{DE}$ em ambos os domínios, enquanto no centro da nappe, em situação de patamar eram geradas estruturas com afinidade ao padrão estrutural observado para o DI.

Acreditamos que a transição entre as situações de rampa e patamar se deu por rotação do plano de cisalhamento e do eixo de vorticidade, da posição horizontal (patamar) para a vertical (rampa). Com a continuidade da deformação a nappe de Passos, possivelmente aproveitando uma anisotropia de baixo ângulo pré-existente, cavalgou as rochas do DE obliquamente, sendo a Rampa Lateral de Capitólio sendo melhor classificada como uma rampa oblíqua. Esse cavalgamento possivelmente ocultou a rampa original, limite da nappe de Passos, marcada por um plano íngreme. Esse contato atualmente estaria sotoposto à nappe de Passos.

Estudos posteriores na parte frontal da NP poderiam melhor embasar a veracidade desse modelo, onde teríamos que observar o plano $\mathrm{S}_{2}$, rotacionando até a posição subhorizontal (rampa frontal) e com isso ser mais difícil de distingui-lo do plano $\mathrm{S}_{3}$, formando uma foliação composta.

Agradecimentos À FAPESP processo 05/58411-0, pelo auxílio e fomento aos trabalhos; e ao IBAMA pelo apoio e autorização para trabalharmos no Parque Nacional da Serra da Canastra.

\section{Referências}

Butler R.W.H. 1982. The terminology of strucutures in thrust belts. Journal of Structural Geology, 4(3):239-245.

Boyer S.E. \& Elliot D. 1982. Thrust systems. Bull. Am. Ass. Petrol. Geol., 66:1196-1230
Coward M.P. 1980. Shear Zones in the Precambrian crust of the Southern Africa. Journal of Structural Geology, 2(1/2):19-27.

Coward M.P. \& Potts G.J. 1983. Complex strain patterns de- 
veloped at the frontal and lateral tips to shear zones and thrust zones. Journal of Structural Geology, 5(3/4):383395.

Fossen H. \& Tikoff B. 1998. Extended models of transpression and transtension, and application to tectonic settings. In: Holdswort R.E., Strachan R.A., Dewey J.F. (eds.) 1998. Continental Transpressional and Transtensional Tectonics. Geological Society, Special Publications, London, 135:15-33.

Heilbron M., Valeriano C.M., Zimbres E., Chrispim S.J., Simões L.S.A., Souza M.A.T. 1987. O contato basal do Grupo Canastra entre Itaú de Minas e Carmo do Rio Claro, MG. In: SBG, Simpósio de Geologia de Minas Gerais, 4, Belo Horizonte, Anais, p.179-198.

Lamotte D.F. de \& Guezou J.C. 1995. Distinguishing lateral folds in thrust-systems; examples from Corbières ( $\mathrm{SW}$ France) and Betic Cordilleras (SE Spain). Journal of Structural Geology, 17(2):233-244.

Luvizotto G.L. 2003. Caracterização Metamórfica das Rochas do Grupo Araxá na Região de São Sebastião do Paraíso, Sudoeste de Minas Gerais. Dissertação de Mestrado. Inst. Geociências e Ciências Exatas, UNESP, 185p.

Morales N. 1993. Evolução tectônica do Cinturão de Cisalhamento de Campo do Meio na Porção Ocidental. Tese de Doutoramento, Instituto de Geociências e Ciências Exatas, UNESP, 270p.

Morales N., Carvalho S.G., Choudhuri A., Fiori A.P., Oliveira M.A.F., Rodrigues M.F.B., Soares P.C., Zanardo 1983. A Geologia das Folhas de Fortaleza de Minas, Alpinópolis, Jacuí e Nova Rezende, MG. In: SBG/ Núcleo Minas Gerias, Simpósio de Geologia de Minas Gerais, 5, Belo Horizonte, Anais, v.3, p. 411-422.

Passchier C.W. 1997. The fabric attractor. Journal of Structural Geology, 19:113-127.

Passchier C.W. 1998. Monoclinic model shear zones. Journal of Structural Geology, 20:1121-1137.

Passchier C.W. \& Trouw R.A. 1996. Microtectonics. Berlin, Springer, 289p.

Passchier C.W., den Brok S.W.J., van Gool J.A.M., Marker M., Manatschal G. 1997. A laterally constricted shear zone system - the Nordre Stromfjord steep belt, Nagssugtoqidian Orogen, W. Greenland. Terra Nova, 9:199-202.

Pohn H.A. 2000. Lateral Ramps in the Folded Appalachians and in Overthrust Belts Worldwide - A Fundamental Element of Thrust-Belt Architecture. U. S. Geological Survey Bull, 2163:71p.

Ramsay J.B. \& Huber M.I. 1983. The techniques of modern strucutural geology. v.1: Strain analysis. Academic Press, Inc., 307p.

Sanderson D. \& Marchini R.D. 1984. Transpression zones. Journal of Structural Geology, 6:449-458.

Santos T.E.S.S. dos. 2007. Caracterização Estrutural de um Segmento da Rampa Lateral de Capitólio, Limite Norte da nappe de Passos - MG. Dissertação de Mestrado, Instituto de Geociências e Ciências Exatas, UNESP, 139p.

Schobbenhaus C., Campos D.A., Derze G.R., Asmus H.E. 1984. Geologia do Brasil - Texto Explicativo do Mapa Geológico do Brasil e Área Oceânica Adjacente, incluindo Depósitos Minerais. Brasília, DNPM-DGM, 501p.

Seer H.J., Brod J.A., Fuck R.A., Pimentel M.M., Boaventura
G.R., Dardenne M.A. 2001. Grupo Araxá em sua área tipo: um fragmento de crosta oceânica Neoproterozóica na Faixa de Dobramentos Brasília. Revista Brasileira de Geociências, 31(3):385-396.

Silva C.H. 2003. Evolução Geológica da Faixa Brasília na região de Tapira, Sudoeste de Minas Gerais. Tese de Doutoramento, Inst. de Geociências e Ciências Exatas, UNESP, 196p.

Simões L.S.A. 1995a. Evolução tectono-metamórfica da nappe de Passos, sudoeste de Minas Gerais. Tese de Doutoramento, Instituto de Geociências, USP, 149p.

Simões L.S.A. 1995b. Padrão estrutural de uma rampa lateral da nappe de Passos (MG): Superposição de estruturas associadas às componentes transcorrente e de empurrão. In: Simpósio Nacional de Estudos Tectônicos, 5, Gramado, atas, p. 90-92.

Simões L.S.A. \& Valeriano C.M. 1990. Porção Meridional da Faixa de Dobramentos Brasília: estágio atual do conhecimento e problemas de correlação tectono-estratigráfica. In: SBG, Congresso Brasileiro de Geologia, 36, Natal, Anais, 6:2564-2575.

Teixeira N.A \& Danni J.C.M. 1978. Contribuição à estratigrafia do Grupo Araxá na região de Passos, MG. In: SBG, Congresso Brasileiro de Geologia, 30, Recife, Anais, 2:700-710.

Valeriano C.M. 1992. Evolução tectônica da extremidade Meridional da Faixa Brasília, região da Represa de Furnas, Sudoeste de Minas Gerais. Tese de Doutoramento, Instituto de Geociências, USP, 192p.

Valeriano C.M. 1999. A Faixa Brasília Meridional, com ênfase no segmento de Furnas: estado atual de conhecimento e modelos de evolução tectônica. Tese de Livre Docência, Depart.Geologia Regional e Geotectônica,UERJ, 90p.

Valeriano C.M., Teixeira W., Heilbron M., Simões L.S.A. 2000. Southern Brasília Belt (SE Brazil): Tectonic discontinuities, K-Ar data and evolution during the Neoproterozoic Brasiliano orogeny. Revista Brasileira de Geociências, 20(2):93-110.

Valeriano C.M., Dardenne M.A., Fonseca M.A., Simões L.S.A., Seer H.J. 2004. A evolução tectônica da Faixa Brasília. In: Mantesso-Neto V., Bartorelli A., Carneiro C.D.R., Brito-Neves B.B. 2004 (orgs.) Geologia do Continente Sul-Americano: Evolução da Obra de Fernando Flávio de Almeida. São Paulo, Beca, p. 575-592.

Valeriano C.M., Almeida J. C.H., Simões L.S.A., Duatt B.P., Roig H., Heilbron M. 1995. Evolução estrutural do Domínio Externo da Faixa Brasília no sudoeste de Minas Gerais: registros de uma tectônica pré-Brasiliana. Revista Brasileira de Geociências. 25(4):221-234.

Yardley B.W.D. 1989. Introdução a Petrologia Metamórfica. Tradução de Fuck R.A. 1994. Brasília, Edunb, 340p.

Zanardo A. 1992. Análise petrográfica estratigráfica e microestrutural da região de Guaxupé - Passos - Delfinópolis $(M G)$. Tese de Doutoramento, Instituto de Geociências e Ciências Exatas, UNESP, 288p.

Manuscrito ID 11680 Submetido em 03 de julho de 2008 Aceito em 25 de junho de 2009 